\title{
Extracranial metastases of medulloblastoma in adults: literature review
}

\author{
Semion Rochkind, Ilan Blatt, Menachem Sadeh, Yochanan Goldhammer
}

\begin{abstract}
A consecutive series of 30 cases of extracranial medulloblastoma metastases in adults is analysed. The majority of the patients were males with a 3:1 male/female ratio. Bone was the most frequent site of metastases in adults (77\%) and children (78\%), followed by lymph nodes $(33 \%)$ in both children and adults. Lung metastases were more common in adults (17\%), but liver metastases occurred more frequently in children (15\%). Possible routes of spread and development of metastases are discussed, with special emphasis on the role of shunts in tumour seeding. Distant extracranial metastatic spread of medulloblastoma occurs at the rate of $7 \cdot 1 \%$. Mean interval between operation of the primary tumour and the discovery of metastases was shorter in children (20 months) than in adults (36 months). Survival after the discovery of metastases was also shorter in children ( 5 months) than in adults (9.5 months). Shunts were associated with an earlier appearance of metastases and with a poorer prognosis. A detailed review of the literature of 119 cases of medulloblastoma with extracranial metastases is provided.
\end{abstract}

Reports of primary central nervous system tumours with distant metastatic spread first appeared in $1886^{1}$ and $1889 .^{2}$ These, as well as succeeding cases, concerned meningeal tumours and it was only in 1936 that Nelson ${ }^{3}$ reported the first well-documented case of metastases outside the central nervous system in a patient with cerebellar medulloblastoma. In 1961 Paterson $^{4}$ was the first to publish a series of 35 cases of medulloblastoma, seven of which displayed extracranial metastases. Subsequently, several other series of medulloblastoma with extracranial metastases were published (table 1), as well as numerous single case reports. Most reports to date have involved children, adult cases apparently being much rarer. The present investigation offers a comprehensive survey of the literature on extracranial metastases of medulloblastoma in adults and also an additional case report that provided the stimulus for our review of this rare phenomenon.

Case report

A 33 year old male presented with severe headache and vomiting. On physical examination, he showed bilateral papilloedema and severe ataxia and incoordination. Brain computerised tomography (CT) demonstrated a large mass, $5 \mathrm{~cm}$ in diameter, in the vermis and right cerebellar lobe. Suboccipital craniotomy was performed and a large, soft greyish cerebellar tumour, extending into the roof of the fourth ventricle, was totally excised. The tumour was found to be a medulloblastoma. A post-operative CT scan did not reveal any residual tumour. The patient subsequently received radiation therapy: whole brain-3600 RAD, posterior fossa-5200 RAD, total spine-3000 RAD. On discharge, the patient had no neurological deficit and remained symptomless.

Twenty one months after corrective surgery, however, low back pain and micturition difficulties appeared, and within two weeks, urinary retention developed, with paraparesis and loss of sphincter control. Myelography showed a partial block at $T_{7}$ and a complete block at $T_{3}$, with multiple intradural lesions along the dural sac. CT scan revealed a hypodense area in the roof of the fourth ventricle, containing a discrete area with some contrast enhancement. Bone radio-isotope scan showed increased absorption in thoracic vertebrae $T_{1}-T_{10}$, in most ribs, and in the sternum, pelvis and both femurs. Liver radioisotope scan revealed several foci of increased absorption, and a chest radiograph demonstrated multiple pulmonary metastases. Bone marrow biopsy revealed an infiltration of numerous tumour cells diagnosed as medulloblastoma, with large areas of necrosis and fibrosis. The patient received a course of radiation therapy and a course of C-MOPP. However, his condition gradually deteriorated and he died two months later.

To the best of our knowledge, although questions of incidence of extracranial metastases of medulloblastoma, location, mode of spread and survival have been discussed in previous reviews, none of them have separately discussed the problem of extracranial metastases of medulloblastoma in adults.

\section{Results and comments}

In 1930 Bailley $^{5}$ demonstrated that medulloblastomas tended to seed along cerebrospinal fluid (CSF) pathways, and in the same year Wohlvill ${ }^{6}$ was the first to draw attention to the occurrence of systemic metastasis of a medulloblastoma. Since then, metastases within the central nervous system 
Table 1 Frequency of medulloblastomas with extracranial metastases

\begin{tabular}{|c|c|c|c|}
\hline Authors & $\begin{array}{l}\text { No cases } \\
\text { medulloblastoma }\end{array}$ & $\begin{array}{l}\text { No cases extracranial } \\
\text { metastases }\end{array}$ & $\begin{array}{l}\text { \% Medulloblastoma with } \\
\text { extracranial metastases }\end{array}$ \\
\hline Paterson $^{4}(1961)$ & 35 & 7 & $20 \cdot 0 \%$ \\
\hline Friborsky ${ }^{10}(1963)$ & 6 & 1 & $16 \cdot 7 \%$ \\
\hline Dexter and Howell ${ }^{\text {"I }}$ (1967) & 93 & 3 & $3 \cdot 2 \%$ \\
\hline Bloom et al l2 $^{12}(1969)$ & 82 & 2 & $2 \cdot 4 \%$ \\
\hline Aron $^{13}(1969)$ & 24 & 1 & $4 \cdot 1 \%$ \\
\hline Chatty and Earle ${ }^{14}(1971)$ & 201 & 4 & $2 \cdot 0 \%$ \\
\hline Smith et al ${ }^{15}(1973)$ & 43 & 3 & $7 \cdot 0 \%$ \\
\hline Hoffman et al 10 (1976) & 44 & 6 & $13.6 \%$ \\
\hline Brown et al ${ }^{17}(1977)$ & 14 & 1 & $7 \cdot 1 \%$ \\
\hline Das and Dalby ${ }^{18}$ (1977) & 22 & 3 & $13.6 \%$ \\
\hline Schnitzler and Richardson ${ }^{19}(1978)$ & 28 & 4 & $14 \cdot 3 \%$ \\
\hline Jackson and Graham ${ }^{20}(1978)$ & 100 & 1 & $1.0 \%$ \\
\hline Raimond and Tomita ${ }^{21}(1979)$ & 51 & 0 & 0 \\
\hline Paillas et al ${ }^{22}$ (1979) & 17 & 3 & $17 \cdot 6 \%$ \\
\hline McComb et al ${ }^{23}$ (1981) & 34 & 6 & $17 \cdot 6 \%$ \\
\hline Campbell et al ${ }^{24}(1984)$ & 152 & 15 & $9.9 \%$ \\
\hline Kasantikul et al ${ }^{25}(1986)$ & 35 & 1 & $2.9 \%$ \\
\hline Farwell and Flannery ${ }^{26}(1987)$ & 44 & 12 & $27 \cdot 3 \%$ \\
\hline Total & 1025 & 73 & $7 \cdot 1 \%$ \\
\hline
\end{tabular}

have been found in one third to one half of cases where a careful search of the brain, spinal cord and nerve roots was carried out. ${ }^{7-9}$ Metastases outside the craniospinal axis, however, are much rarer, their overall incidence comprising $7 \cdot 1 \%$ (table 1 ).

Age and sex distribution

In searching the literature, 119 cases of medulloblastoma with extracranial metastases were found, $89(75 \%)$ of which were in children, $816182023-2527-55$ and $30(25 \%)$ in persons aged 17 or older (table 2 ). The age range of afflicted adults was between 17 and 46 years, with a mean of 25 for both males and females. A marked overall male predominance is evident from the literature, with a 3:1 male/female ratio, but for medulloblastoma in adult patients without extracranial metastases, the male/ female ratio was $2: 1 .^{31}$

When compared with extracranial metastases of astrocytomas and glioblastomas, ${ }^{69}$ it was found that metastases occurred mainly in adults (63 cases or $88 \%$ ). In our study of extracranial metastases of medulloblastoma, the percentage of adult cases was only $25 \%$.

\section{Location of metastases}

Bone was the most frequent site for extracranial metastases, both in adults ( $77 \%$ of cases) and in children ( $78 \%$ ). Lymph node metastases were second in frequency, with an incidence of $33 \%$ in both adults and children. In third place in adults, were the lungs $(17 \%)$, followed by muscle $(13 \%)$ and liver $(10 \%)$. In children, however, liver metastases were more frequent $(15 \%)$ and lung metastases less frequent $(11 \%)$ than in adults $(17 \%)$, while muscle was a rare target $(2 \%)$ of metastatic spread (table 3 ). In both adults and children, the lesions usually involved the axial skeleton, the pelvic and shoulder girdle and adjacent ends of long bones, the ribs and the skull. Occasionally, there was periosteal new bone formation. Metastases which initiated reactive new bone formation were well visualised radiographically. ${ }^{63}$ An unusual coupling of leukoerythroblastic anaemia with diffuse osteosclerosis was reported in a 25 year old man..$^{59}$

The liver was the most frequent site of metastases $(13 \%)$ of the abdominal viscera in adults and children. Several cases, however, showed extensive deposits in other abdominal

Table 2 Localisation of the metastases in cases of medulloblastoma in adults

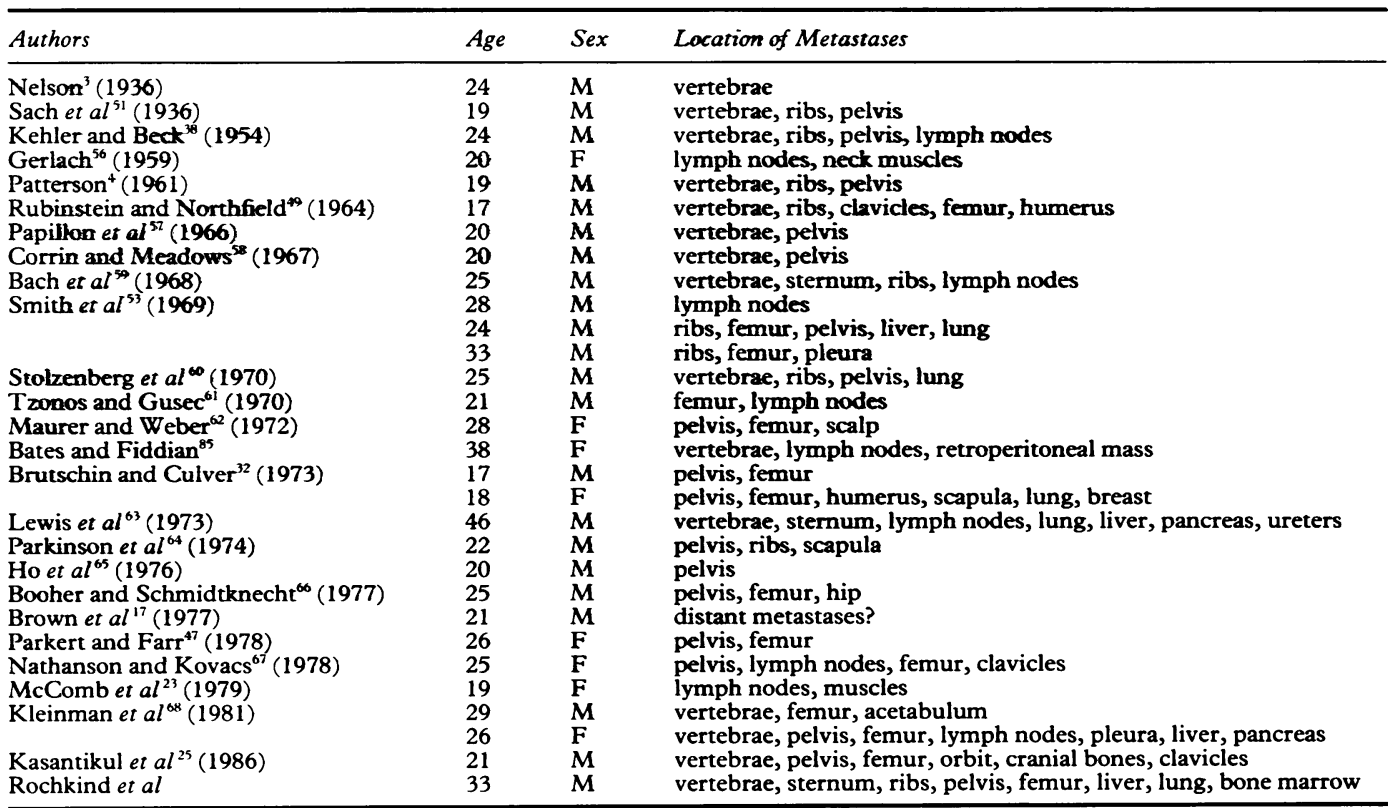


Table 3 Site of extracranial metastases of medulloblastoma in children and adults

\begin{tabular}{|c|c|c|c|c|}
\hline \multirow[b]{2}{*}{ Site of Metastases } & \multicolumn{2}{|l|}{ Children } & \multicolumn{2}{|l|}{ Adults } \\
\hline & No cases $(n=89)$ & $\%$ Total cases & No cases $(n=30)$ & $\%$ Total cases \\
\hline $\begin{array}{l}\text { Skeleton } \\
\text { Lymph nodes } \\
\text { Lung } \\
\text { Liver } \\
\text { Muscle } \\
\text { Other }\end{array}$ & $\begin{array}{r}69 \\
29 \\
10 \\
13 \\
2 \\
28\end{array}$ & $\begin{array}{r}78 \\
33 \\
11 \\
15 \\
2 \\
32\end{array}$ & $\begin{array}{r}23 \\
10 \\
5 \\
3 \\
4 \\
6\end{array}$ & $\begin{array}{l}77 \\
33 \\
17 \\
10 \\
13 \\
20\end{array}$ \\
\hline
\end{tabular}

organs such as the pancreas (4\%). Additional sites occasionally involved were kidneys $(2 \%)$, ureters $(1 \%)$, testes $(2 \%)$, ovaries $(1 \%)$, breast $(1 \%)$ and thymus $(1 \%)$. It is interesting that no tumour deposits have ever been found in the adrenals, a fact first noted by Smith et al $^{42}$ in their small-scale study (eight cases) of extracranial medulloblastoma metastasis, and also clearly borne out in the present survey of 119 cases.

Among the neuroectodermal tumours which gave rise to extracranial metastases, medulloblastoma is second in frequency, the first being glioblastoma multiforme. . $^{-34570}$ Although the most common childhood brain tumour to spread outside the central nervous system is medulloblastoma, ${ }^{71}$ the extracranial metastases of glioblastoma have a different pattern of spread, from those of medulloblastoma (table 4). Thus bone metastases being by far the most common with medulloblastoma $(78 \%)$, occur in only $30 \%$ of cases with metastatic glioblastoma and astrocytoma. ${ }^{69}$ Conversely, the lung is the most frequent site of spread of glioblastoma and astrocytoma $(60 \%)$, but is much less frequently affected in medulloblastoma $(13 \%)$. Lymph node metastases have approximately the same high frequency in both primary tumours, glioblastoma $(51 \%)$ and medulloblastoma $(33 \%)$. The liver is less frequently involved in medulloblastoma $(13 \%)$ than in glioblastoma $(22 \%)$. In our survey of 89 cases of extracranial medulloblastoma metastases in children, the most frequent sites were bone $(78 \%)$, lymph nodes $(33 \%)$, liver $(15 \%)$ and lung $(11 \%)$ (table 3$)$. In children with other types of intracranial tumours, the most common sites were: lung $(79 \%)$, lymph nodes $(39 \%)$ and bone $(25 \%) .^{24}$

Routes of spread

It is interesting to speculate on the routes whereby medulloblastoma cells reach distant sites. Direct lymphatic spread is impossible, because true lymphatics are not present in the central nervous system. However, the lymph nodes may become secondarily involved by spread from an extranodal metastatic deposit. It is also possible that spread of tumour

Table 4 Comparison of site of extracranial metastases in neuroectodermal tumours

\begin{tabular}{lll}
\hline Site of metastases & Medulloblastoma & $\begin{array}{l}\text { Astrocytoma and } \\
\text { glioblastoma }\end{array}$ \\
\hline Bone & $78 \%$ & $30 \%$ \\
Lymph nodes & $33 \%$ & $51 \%$ \\
Lung & $13 \%$ & $60 \%$ \\
Liver & $13 \%$ & $22 \%$ \\
\hline
\end{tabular}

in continuity along nerve roots may lead to invasion of lymphatics, ${ }^{18}$ and indeed Oberman $^{46}$ has reported the presence of tumour cells in peripheral lymphatics. Local lymphatic extension to the extracranial tissues of the head and neck is suggested from cases that have demonstrated either scalp masses or cervical lymph node involvement. ${ }^{4} \mathrm{McComb}$ et al ${ }^{72}$ described two cases of infants with soft tissue masses in the neck, whose necropsy examination revealed primary medulloblastoma of the cerebellar vermis with extensive spread through the subarachnoid space; the tumour locally infiltrated the bone marrow, fat, muscles and lymph nodes. Russel and Rubenstein ${ }^{50}$ conjectured that small veins might be the route of extracranial dissemination because tumour cells penetrating blood vessels, tumour invasion of dural veins, or direct extension to the cranium or to the operative site, are almost always encountered. By now, the haematogenous route of spread is accepted by most authors and indeed the prevalence and distribution of skeletal metastases are consistent with the haematogenous mode of spread. ${ }^{63}$

Two unusual cases of intramedullary lesions 13 months and two and a half years after resection of cerebellar medulloblastomas have been reported..$^{30}$ There was no evidence of subarachnoid spread of the tumour. These reports suggested that the tumour had spread from the cerebellum through the central canal of the spinal cord.

\section{Extravasation and development of metastases}

The first step in the metastatic process is that the primary tumour mass must generate variant cells that can break away, penetrate the surrounding stromal tissue, and make their way into the circulation. ${ }^{73}$ After they invade the blood vessels, single tumour cells or multicell emboli circulate and eventually reach the capillary bed of distant organs, where they are arrested. Interactions of metastatic cells with the microvasculature evoke inflammatory responses that provide sources of enzymes and could enhance extravasation of tumour cells into the organ parenchyma. After metastatic cells extravasate into the organ parenchyma, they must proliferate in order to give rise to secondary lesions. ${ }^{74-76}$ However, in vitro studies indicate that variation in the surface properties of endothelial cells from different target organs may partially account for differences in the binding of circulating cancer cells, which leads to organ preference in metastatic localisation. ${ }^{77}$ 
Table 5 Correlation of shunt procedure with extracranial metastases of medulloblastoma

\begin{tabular}{|c|c|c|}
\hline Authors & $\begin{array}{l}\text { No of cases with extracranial } \\
\text { metastases following shunt } \\
\text { procedure }\end{array}$ & Location of metastases \\
\hline 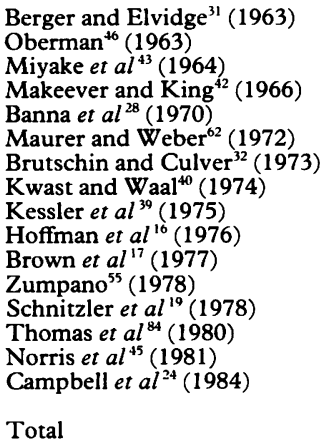 & $\begin{array}{l}2 \\
1 \\
1 \\
1 \\
1 \\
1 \\
1 \\
1 \\
1 \\
4 \\
1 \\
1 \\
1 \\
1 \\
1 \\
15\end{array}$ & $\begin{array}{l}\text { skeleton-1, peritoneum-2 } \\
\text { skeleton-1, lymph nodes-1 } \\
\text { skeleton, lymph nodes, liver, scalp } \\
\text { lung, lymph nodes, pleura, diaphragm } \\
\text { skeleton } \\
\text { pelvis, femur, scalp } \\
\text { skeleton, lymph nodes, lung } \\
\text { jaw } \\
\text { skeleton } \\
\text { skeleton-3, bone marrow-4, liver-1, pleural effusion-1 } \\
\text { distant metastases? } \\
\text { intramedullary in spinal cord } \\
\text { vertebrae, pelvis, ribs, sternum, femur, humeri } \\
\text { bone marrow } \\
\text { skeleton } \\
\text { skeleton-14, bone marrow-9, peritoneum-5, liver-3, } \\
\text { lung-1, kidney-1, bowel-1, lymph nodes-1 }\end{array}$ \\
\hline
\end{tabular}

Metastases and immune system

Most non-haematopoetic cancer cells detected in the bloodstream are dead ${ }^{75}$ and only one in 10000 cells entering the circulation succeeds in establishing a new metastatic lesion. ${ }^{78}$ Two distinct mechanisms are probably responsible for the death of most metastatic cells. To some extent, natural host immunity is able to destroy malignant cells. ${ }^{73}$ Natural killer (NK) cells and macrophages, appear to be a major means of eliminating tumour cells. ${ }^{80}$ Immune reactions against tumour-specific antigenes generate target-specific cytotoxic $T$ cells and lead to the production of lymphokines which in turn promote additional cytotoxic reactions by lymphokine-activated killer (LAK) cells. $^{8081}$ However, even under optimal circumstances, the defence system cannot account for the rapid destruction of almost all circulating tumour cells. $^{82}$

\section{Shunt procedures and metastatic spread} In 1963, Abraham and Chandy ${ }^{83}$ pointed out the value of a precraniotomy shunt in the management of patients with a posterior fossa tumour. Hoffman et al $^{16}$ who routinely inserted ventriculoperitoneal shunts in all patients with posterior fossa tumour and hydrocephalus, seven to 10 days before craniotomy, found that of 41 patients with medulloblastoma thus treated, four had metastasised through the shunt. Kessler et $a l,{ }^{39}$ in reviewing 53 cases of systemic metastases of medulloblastoma, found eight to be associated with shunts. Two of these shunts were ventriculoperitoneal, ${ }^{31}$ five were ventriculoatrial ${ }^{28324662}$ and one was both ventriculoatrial and lumboperitoneal. ${ }^{39}$ With a ventriculoatrial shunt, the direct pathway shunting CSF to the blood is rather obvious and it is reasonable to attribute spread of the tumour into bone, lymph nodes, liver, lung, etc to an intravascular dissemination which might well be promoted by the shunting. Similarly with ventriculoperitoneal shunt, peritoneal seeding has been described, ${ }^{31}$ with the seeding specifically evident around the peritoneal end of the shunt tube. Lumboperitoneal shunt apparently also served as direct pathway in the case of a tumour mass surrounding the tip of the catheter. ${ }^{39}$ Several other authors ${ }^{17} 42454$ have likewise ascribed the appearance of distant metastases to ventriculoperitoneal or ventriculoatrial shunts. Table 5 lists all reported cases of extracranial metastases of medulloblastoma with site of location in patients that had had a shunt procedure.

A shunt seems to be associated with a significantly earlier appearance of extracranial metastases in both children and adults, and with a poorer prognosis in children (table 6). Thus in children without a shunt, metastases are discovered after a mean interval of 24 months from the first operation, whereas in children with a shunt, this interval diminished to 13 months. In adults, the mean disease duration until the detection of extracranial

Table 6 Shunt procedure correlated with duration of disease until detection and with survival following detection of extracranial metastases

\begin{tabular}{lccc}
\hline & No of patients & $\begin{array}{l}\text { Mean duration of symptoms until } \\
\text { recognition of metastases }\end{array}$ & $\begin{array}{c}\text { Mean survival after } \\
\text { recognition of metastases }\end{array}$ \\
\hline $\begin{array}{l}\text { Adults } \\
\text { Without shunt }\end{array}$ & 23 & 39 months & 10 months \\
With shunt & 25 & 8 months \\
$\begin{array}{l}\text { Total } \\
\text { \% patients with shunt procedure }\end{array}$ & $25 \star$ & & \\
$\begin{array}{l}\text { Children } \\
\text { Without shunt }\end{array}$ & $8 \%$ & & 6 months \\
With shunt & 51 & 24 months \\
$\begin{array}{l}\text { Total } \\
\text { \% patients with shunt procedure }\end{array}$ & 28 & 13 months & 3 months \\
\hline
\end{tabular}

*In five additional adult cases and ten children, data were lacking regarding the performance of shunts.

$\star \star$ Five other adults and three children were still alive when reported ${ }^{30} 335506065685$ and were not included in this table. $\star \star \star$ One other child was still alive when reported and was not included in this table. 
metastases is 39 months in those without a shunt versus eight months in those with a shunt. Mean survival after detection of metastases is six months in children without a shunt, and three months in children with a shunt, while in adults the corresponding means are 10 months and four months, respectively. A shunt procedure thus seems to exert an adverse effect on the course and prognosis of the disease.

Disease duration and survival after recognition of metastases

Mean duration from excision of the primary tumour to discovery of metastases is 36 months in adults (range two to 120 months). In children, this interval is much shorter, with a mean of 20 months (range 0.6 to 76 months). Although the time interval from the operation may be as long as 10 years, as in one of Stolzenberg's cases. ${ }^{60}$

Mean survival after the discovery of extracranial metastases is 9.5 months in adults (range 0.2 to 24 months). The prognosis is poorer in children with a mean survival of only five months (range 0 to 18 months). Of interest is the case report of a patient who was still alive four years after the discovery of metastases. ${ }^{23}$

\section{Treatment}

In $1930 \mathrm{Cushing}^{86}$ was the first to report the use of total CNS irradiation in medulloblastoma. Currently, the standard therapy for medulloblastoma after surgery, includes postoperative craniospinal irradiation, ${ }^{41}$ which has a five year survival rate of between $40 \%$ to $60 \%$. The majority of children surviving medulloblastoma who have received wholebrain radiotherapy are severely intellectually impaired ${ }^{87}$ Moreover, high frequency of gross hormone (GH) deficiency and thyroid dysfunction have been reported as a consequence of cranial radiation. 8889

The International Society of Pediatric Oncology, ${ }^{90}$ the Children Cancer Study Group $^{91}$ and other sources ${ }^{9293}$ have indicated that chemotherapy may delay, but does not ultimately prevent, recurrence of the malignancy. Yet, chemotherapy has been found most useful in young children with extensive tumour invasion and incomplete resection. ${ }^{91}$ Medulloblastomas respond to chemotherapeutic agents that normally have limited access to brain: cyclophosphamide is water soluble and crosses the blood-brain barrier slowly; and vincristine exhibits high protein binding in plasma, which limits access to the normal brain. $^{9495}$ An interesting effect of chemotherapy on the radiological appearance of skeletal metastases of medulloblastoma has been demonstrated, ${ }^{28}$ wherein radiograms taken a few months after the administration of the cytotoxic drug, revealed gradual reossification of the osteolytic lesions and disappearance of the periosteal new bone.

Treatment of extracranial metastases of medulloblastoma may be carried out in one of four ways: ${ }^{19}$ radiation therapy alone, ${ }^{414283649}$ radiation therapy combined with chemotherapy, ${ }^{34} 37456063$ chemotherapy alone ${ }^{3263729697}$ and supportive treatment without any radiotherapy or chemotherapy. ${ }^{4}$

Treatment outcome in adults in terms of survival is shown in table 7 . In this study we did not find a significant difference between survival after recognition of metastases and type of treatment. Mean survival after discovery of extracranial metastases and additional treatment was 10 months for radiotherapy treated group, seven months for chemotherapy treated group, nine months for radiotherapy with chemotherapy treated group and nine months for supportive treatment group.

It is now well known that endothelial damage facilitates metastatic cell arrest by causing exposure of the basement membrane. ${ }^{98}$ Agents that damage the endothelium can enhance formation of spontaneous metastases. These agents include commonly employed antineoplastic drugs, oxygen and x-ray. ${ }^{99}$

Cancer treatments that destroy most, but not all, of the tumour cells may be stimulating the surviving cells to quickly produce new generations of tumour cell variants that may be more metastatic and resistant to treatment. ${ }^{100}$

\section{Conclusions}

Discovery of extracranial metastases of medulloblastoma augurs ill for all age groups, for by then there is already widespread dissemination, and the response to treatment is at best limited. In adults, the sites of metastases are somewhat different than in children, the time interval until the appearance of metastases is longer, and survival is better. In patients of all ages, shunt procedure carries the risk of providing a route for tumour dissemination and should therefore be employed only where absolutely necessary.

We are grateful to Mrs Eva McGrath for word processing assistance.

1 Power D. Fibro-sarcoma of the dura mater. Trans Path Soc Lond 1886;37:12-14.

Klebs E. Ellgemeine-pathologie Vol 2. Vienna: Gustav Fischer; 1889:628-34.

3 Nelson AA. Metastases of intracranial tumor. Am J Cancer 1936;28:1-12.

4 Paterson E. Distant metastases from medulloblastoma of the cerebellum. Brain 1961;84:301-9.

5 Bailley P. Further notes on the cerebellar medulloblastomas. The effect of roentgen radiation. Am J Path

Table 7 Results of treatment of extracranial metastases in adults. ${ }^{\star}$ Mean survival after recognition of metastases

\begin{tabular}{llll}
\hline Radiotherapy only $(n o=5)$ & Chemotherapy only $(n o=4)$ & $\begin{array}{l}\text { Radiotherapy with } \\
\text { chemotherapy }(n o=2)\end{array}$ & $\begin{array}{l}\text { Supportive treatment only } \\
(n o=4)\end{array}$ \\
\hline 10 months $^{\star \star}$ & 7 months & 9 months $\star \star$ & 9 months
\end{tabular}

$\star 12$ additional cases were not included in this table because of insufficient data regarding the mode and outcome of treatment. $\star \star$ Another patient who received radiotherapy only, and two other patients who received a combination of radiotherapy and chemotherapy, were still alive when reported and were not included in this table. 
1930;6:126-36

6 Wohlwill F. Zur pathologischen anatomie der malignen medianen kleinhirntumoren der kinder (sop
"Medulloblastoma"). Ztschr $f d$ ges Neurol Psychiat 1930;128:587-614.

7 Abbot KH, Kernohan JW. Medulloblastomas. Bull LA Neurol Soc 1943;8:1-10.

8 Ingraham FD, Bailey OT, Barker WF. Medulloblastoma cerebelli: diagnosis, treatment and survivals with a report cerebelli: diagnosis, treatment and survivals with

9 Strang RR. Intraspinal metastases from medulloblastoma of the posterior fossa. Med J A ust 1962;2:507-10.

10 Friborsky V. Medulloblastoma of the cerebellum. Extracranial metastases and diagnostical difficulties. Neoplasma 1963;10:427-40.

1 Dexter D, Howell DA. Medulloblastoma and arachnoidal sarcomas. Brain 1967;88:367-74.

12 Bloom HJG, Wallace ENK, Henk JW. The treatment and prognosis of medulloblastoma in children. A study of 82 varified cases. Am J Roent Rad Ther Nucl Med 1969; 105:43-62.

13 Aron BS. Twenty years experience with radiation treatment of medulloblastoma. Am J Roent Rad Ther Nucl Med 1969;105:37-42.

14 Chatty EM, Earle KM. Medulloblastoma. A report of 201 cases with emphasis on the relationship of histologic cases with emphasis on the relationship of
variants to survival. Cancer 1971;28:977-83.

15 Smith CE, Long DM, Jones TK, Levitt SH. Experience in treating medulloblastoma at the University of Minnesot Hospitals. Radiology 1973;109:179-82.

16 Hoffman HJ, Hendrie EB, Humphreys RP. Metastases vi ventriculoperitoneal shunt in patients with medulloblas toma. J Neurosurg 1976;44:562-6.

17 Brown RC, Gunderson L, Plenk HP. Medulloblastoma. A review of the LDS Hospital experience. Cancer 1977; 40:56-60.

18 Das S, Dalby JE. Distant metastases from medulloblastoma. Acta Radiol Ther Physic Biol 1977;16:117-23.

19 Schnitzler ER, Richardson MJ. Cerebellar medulloblastoma. An analysis of four cases with extraneural metastases. Am J Dis Child 1978;132:1004-8.

20 Jackson AM, Graham DI. Remote metastases from intracranial tumors. $J$ Clin Path 1978;31:794-802.

21 Raimond AJ, Tomita T. Medulloblastoma in childhood. Acta Neurochir (Wien) 1979;50:127-38.

22 Paillas JE, Hasson J, Torres-Garcia P, et al. Les medulloblastomas de l'adulte, etude clinique, anatomique et therapeutique de dix-sept observations. Arch Anat Cytol Path 1979;27:78-84.

23 McComb JG, Davis RL, Isaacs H. Extraneural metastatic medulloblastoma during childhood. Neurosurgery 1981 9:548-51.

24 Campbell AN, Chan HSL, Becker LE, et al. Extracranial metastases in childhood primary intracranial tumors. Cancer 1984;53:974-81.

25 Kasantikul V, Shuangshoti S. Cerebellar medulloblastomas: a study of 35 cases with particular reference to cellular differentiation. Surg Neurol 1986;26:532-41.

26 Farwell JR, Flannery JT. Adult occurrence of medulloblastoma. Acta Neurochir (Wein) 1987;86:1-5.

27 Auriol M, Foncin JF, Schwiesguth O. Metastase en dehors du nevraxe d'un medulloblastome cerebelleux a differenciation neuroblastique (etude anatoma-clinique). Arch ciation neuroblastique (etude anat

28 Banna M, Lassman LP, Pearce GW. Radiological study of skeletal metastases from cerebellar medulloblastoma. $B$ J Radiol 1970;43:173-9.

29 Barden RP, Lewey FH. Metastasizing cerebellar tumors. The difficulty in distinguishing between medulloblastoma and neuroblastoma. $J$ Neurosurg 1949;6:439-49.

30 Barnwell SL, Edwards MSB. Spinal intramedullary spread of medulloblastoma. Case report. J Neurosurg 1986; 65.253-5.

31 Berger EC, Elvidge AR. Medulloblastomas and cerebellar sarcomas. J Neurosurg 1963;20:139-44.

32 Brutschin P, Culver GJ. Extracranial metastases from medulloblastoma. Radiology 1973;107:359-62.

33 Buchmann E, Zulch KJ. Zur Frage der postoperativen uberlebensdauer und der Fernmetastasierung beim Medulloblastoma des Klenhirns. Acta Neurochir 1959; 7:263-73.

34 Debman JW, Staple TW. Osseous metastases from cerebellar medulloblastoma. Radiology 1973;107:363-5.

35 Drachman DA, Winter TS, Karon M, et al. Medulloblastoma with extracranial metastases. Arch Neurol 1963; 9:86-98.

36 Duckett S. Medulloblastoma with extraneural secondaries. Acta Neurol Scand 1963;39:242-51.

37 Gyepes MT, d'Angio GJ. Extracranial metastases from CNS tumours in children and adolescents. Radiology CNS tumours

38 Kehler WH, Beck E. Cerebellar sarcoma with bone metastases. Radiology 1954;63:736-40.

39 Kessler LA, Dugan P, Concannon JP. Systemic metastases of medulloblastoma promoted by shunting. Surg Neurol 1975;3:147-52.

40 Kwast WAM, Waal I. Jaw metastases. Oral Surg 1974 37:850-7.

41 Landberg TG, Lindgren ML, Cavallin-Stahl EK, et al. Improvements in the radiotherapy of medulloblastom 1946-1975. Cancer 1980;45:670-8.

42 Makeever LC, King JD. Medulloblastoma with extracranial metastasis through a ventriculovenous shunt. Am $J$ Clin Path 1966;46:245-9.
43 Miyake S, Toyama M, Etani B, et al. Cerebellar medulloblastoma with postoperative extracranial spread. J Neurosurg 1964;21:416-18.

44 Noel G, Selosse P, Compel C, et al. Metastases extraneurales de medulloblastomes (deux observations). Neurochir 1967;10:216-23.

45 Norris DG, Bruce DA, Byrd RL, et al. Improved relapsefree survival in medulloblastoma utilizing modern techniques. Neurosurgery 1981;9:661-4.

46 Oberman HA, Hewitt WC, Kalwoda AJ. Medulloblastoma with distant metastases. Am J Clin Path 1963:39:148-60.

47 Parkert RC, Farr GHJ. Medulloblastoma metastatic to bone. Clin Bulletin 1978;8:38-40.

48 Black SP, Keats TE. Generalized osteosclerosis secondary to metastatic medulloblastoma of the cerebellum. Radio 1964;82:395-400.

49 Rubinstein LJ, Northfield DW. Medulloblastoma and the so-called "arachnoidal cerebellar sarcoma", critical reexamination of a nodological problem. Brain 1964;87 379-412.

50 Russell DS, Rubinstein LJ. Pathology of tumors of the nervous system. Baltimore: The Williams and Wilkin Company, 1959:208-10

51 Sachs E, Rubinstein JE, Arneson AN. Results of roentgen treatment of a series of one hundred and nineteen gliomas. Arch Neurol Psychiatry 1936;35:597-615.

52 Schenk EA. Medulloblastoma: relationship to meningeal sarcoma. Arch Path 1966;82:363-8.

53 Smith DR, Hardman JM, Earle KM. Metastasizing neuroectodermal tumors of the central nervous system. $J$ Neurosurg 1969;31:50-8.

54 Van Epps RR, Samuelson DR, McCormick WF. Cerebellar medulloepithelioma. J Neurosurg 1967;27 568-73.

55 Zumpano BJ. Spinal intramedullary metastatic medulloblastoma. Case Report. J Neurosurg 1978;48 $632-5$

56 Gerlach J. Zur Frage Der Metastasierung von Hirngeschwulsten in den Korper. Zentralblt Neurochir 1959;19. 292-8.

57 Papillon J, Lecuire J, Chassard JL, et al. Metastase osseuses d'un medulloblastome de la fossa cerebrale posterieure (a propos d'une observation). J Radiol d'Elect Med Nucl 1966;48:421-3.

58 Corrin B, Meadows JC. Skeletal metastases from cerebellar medulloblastoma. Br Med J 1967;2:485-6.

9 Bach M, Simpson WJ, Platts ME. Metastatic cerebella sarcoma (desmoplastic medulloblastoma) with diffuse osteosclerosis and leukoerythroblastic anemia. A report of a case and review of the literature. Am J Roentgen Rad Ther Nucl Med 1968;103:38-43.

60 Stolzenberg J, Fisher JJ, Kligerman MM. Extradural metastases in medulloblastoma 10 years after treatment. Report of case. Am J Roentgen Rad Ther Nucl Med 1970;108:71-4.

61 Tzonos T, Gusec W. Beitrag zur fernmetasasierung der medulloblastome. Zentralblt Neurochir 1970;31:61-68.

62 Maurer R, Weber G. Medulloblastoma in 4 ventrikel mit metastasierung in das skelett. Schweiz Arch Neurol Neurochir Psychiat 1972;111:353-61.

63 Lewis MB, Nunes LB, Powell DE, et al. Extracrania spread of medulloblastoma. Cancer 1973;31:1287-97.

64 Parkinson D, Ross RT, Shields CR. Metastatic medulloblastoma. Can J Neurol Sci 1974;1:253-4.

65 Ho EP, Lieber AN, Deland FH, et al. Generalized osteoblastic metastases from medulloblastoma. Oncology 1976;33:253-6.

66 Booher KR, Schmidtknecht TM. Cerebellar medulloblastoma with skeletal metastases. J Bone Joint Surg 1977; 59(A):684-6.

67 Nathanson L, Kovacs SG. Chemotherapeutic response in metastatic medulloblastoma. Report of two cases and a review of the literature. Med Pediatr Oncol 1978;4: 105-10.

68 Kleinman GM, Hochberg FH, Richardson EP. Systemic metastases from medulloblastoma: Report of two case

69 Pasquier B, Pasquier D, N'Golet A, et al. Extracranial metastases of astrocytomas and glioblastomas. Clinicopathological study of two cases. Cancer 1980;45:112-25.

70 Glasauer FE, Yuan RHP. Intracranial tumors with extracranial metastases. J Neurosurg 1963;20:474-93.

71 Hoffman HJ, Duffner PK, Extraneural metastases of central nervous system tumors. Cancer 1985, 56(Suppl): 1778-82.

72 McComb JG, Davis RL, Isaacs H, et al. Medulloblastoma presenting as neck tumor in 2 infants. Ann Neurol 1980;7:113-17.

73 Liwnicz BH, Rubinstein LJ. The pathways of extraneura spread in metastasizing gliomas: A report of three cases and critical review of the literature. Hum Pathol 1979; 10:453-67.

74 Poste G Fidler IJ. The pathogenesis of cancer metastasis. Nature 1979;283:139-46.

75 Weiss L. Principles of metastasis. Orlando: Academic Press, 1985.

76 Willis RA. The spread of tumours in the human body. London: Butterworth, 1972 .

77 Auerbach R, Wei Cheng L, Pardon E, Gumkowski F Kaminska G, Kaminski M. Specificity of adhesion between tumor cells and capillary endothelium: an in vitro correlate of preferential metastasis in vivo. Cancer Res 1987;47:1492-6.

78 Fidler IJ. Review: Biologic heterogenity of cancer meta- 
stases. Breast Cancer Res Treat 1987;9:17-26.

79 Hanna N. Role of natural killer cells in control of cance metastasis. Cancer Metastasis Rev 1982;1:45-64.

80 Welch DR, Tomasovic SP. Implications of tumor progression on clinical oncology. Clin Exp Metastasis 1985;3:151-88.

81 Kay NE. Natural killer cells. Crit Rev Clin Lab. Sci 1986;22:343-59.

82 Fidler IJ, Kripke ML. Tumor cell antigenicity, host immunity and cancer metastasis. Cancer Immunol Immunother 1980;7:201-5.

83 Abraham J, Chandy J. Ventriculo-atrial shunt in the management of posterior fossa tumors. Preliminary management of posterior fossa

84 Tromas PRM, Duffiner PK, Cohen ME et al. Multimodality therapy for medulloblastoma. Cancer 1980; modality.

85 Bates T, Fiddian RV. Extracranial metastases from medulloblastoma. Proc R Soc Med 1973;66:652-4.

86 Cushing $H$. Experiences with cerebellar medulloblastomas-critical review. Acta Pathol Microbiol Scand 1930;7:1-86.

87 Raimondi AJ, Tomita $T$. The advantages of total resection of medulloblastoma and disadvantages of whole brain postoperative radiation therapy. Child's Brain 1979; 5:50-9.

88 Oberfield SE, Allen JC, Pollack J, New MI, Levine LS Long-term endocrine sequalae after treatment of medulloblastoma: Prospective study of growth and medulloblastoma: Prospective study of

89 Pasquallini T, Diez B, Domene $\mathrm{H}$, et al. Long-term sequalae after surgery, radiotherapy, and chemotherapy sequalae after surgery, radiotherapy, and chemotherapy
in children with medulloblastoma. Cancer 1987;59: $801-6$.
90 Gerosa MA, de Stefano E, Olivi A, et al. Multidisciplinary treatment of medulloblesto 5 -year experience with treatment of medulloblastoma: a 5-year experin

91 Choux H, Lena G, Hassoun J. Prognosis and long-term follow-up in patients with medulloblastoma. Clin Neurosurg 1983;30:246-77.

92 Berry MP, Jenkin RDT, Keen CW, et al. Radiation treatment for medulloblastoma. A 21-year period. $J$ Neurosurg 1981;55:43-51.

93 Quest DO. Medulloblastoma: biological characteristics and therapy. Contemp Neurosurg 1980;2:1-6.

94 Allen JC, Helson L. High-dose cyclophosphamide chemotherapy for recurrent CNS tumors in children. $J$ Neurosurg 1981;55:749-56.

95 Friedman HS, Mahaley MS, Schold SC, et al. The efficacy of vincristine and cyclophosphamide in the therapy of vincristine and cyclophosphamide in the therapy $335-40$.

96 Lassman LP. Diagnosis and management of skeletal metastases from cerebellar medulloblastoma. Child's Brain stases from cere

97 Lassman LP, Pearle G, Banna M, et al. Vincristine sulphate in the treatment of skeletal metastases from cerebella medulloblastoma. J Neurosurg 1969;30:42-49.

98 Weiss L, Orr FW, Honn KV. Interaction of cancer cells with the microvasculature during metastases. FASEB 1988;2:12-21.

99 Adamson IYR, Yong L, Orr FW. Tumor metastasis after hyperoxic injury and repair of the pulmonary endothelium. Lab Invest 1987;57:71-77.

100 Aukerman SL, Price JE, Fidler IJ. Different difficiencies in the prevention of tumorgenic-low-metastatic murine $\mathrm{K}$ 1735 malanoma cells from producing metastases. JNCI 1735 malanoma 